\title{
Polymorphism of the CYP1A1 and glutathione-S-transferase genes in Korean lung cancer patients
}

\author{
Young-Sook Hong ${ }^{1,4}$, Jung-Hyun Chang ${ }^{2}$, \\ O-Jung Kwon ${ }^{3}$, Yoon-Ae Ham ${ }^{1}$ and \\ Ji-Hyung Choi ${ }^{1}$ \\ 1 Department of Biochemistry, Medical Research Center, Division of Cancer \\ Research, College of Medicine, Ewha Womans University, Seoul 158-056, Korea \\ 2 Department of Internal Medicine, College of Medicine, Ewha Womans University, \\ Seoul 158-056, Korea \\ 3 Department of Internal Medicine, College of Medicine, Sung Kyun Kwan University, \\ Seoul 135-710, Korea \\ 4 Corresponding author
}

Abbreviations: CYP1A1, cytochrome P4501A1; GSTM1, glutathione-S-transferase $\mu$; $\mathrm{AHH}$, aromatic hydrocarbon hydroxylase; RFLP, restriction fragment length polymorphism

\begin{abstract}
The levels of expressions and catalytic activities of cytochrome P450 (CYP1A1) and glutathione-S-transferase class $\mu$ (GSTM1) enzymes in lungs and their metabolic balance may be an important determinant host factor underlying lung cancer. Genetic differences in metabolism, Mspl restriction sites, Ile-Val polymorphism of CYP1A1 gene, and the null genotype of GSTM1 have been reported to be associated with susceptibility to lung cancer. The present studies were undertaken to establish frequencies of the polymorphic genotypes of CYP1A1 and GSTM1 in Koreans, and to evaluate linkage disequilibrium of the genotypes associated with higher lung cancer risks among Koreans. GSTM1(-) genotype was found in $52 \%$ of control subjects, whereas it was found in $55 \%$ of lung cancer patients. The allelic variants in CYP1A1 were distributed differently in lung cancer patients and controls. The heterozygous genotype frequency of the Mspl site in lung cancer patients $(53 \%)$ was higher than in controls $(49 \%)$. The frequency of Ile/Val genotype of CYP1A1 was low in lung cancer patients, which are mostly squamous cell carcinoma.
\end{abstract}

Keywords: CYP1A1, GSTM1, polymorphism

\section{Introduction}

Individual differences in the ability to metabolize xeno- biotics may be a key factor in the genetic predisposition or host susceptibility to various carcinogens (Idle, 1991; Nebert, 1991). The cytochrome P450-dependent monooxygenases are important in the metabolism of environmental carcinogens. CYP enzymes are involved in metabolic activation of procarcinogens to reactive metabolites, and several of these enzymes have been shown to be polymorphically distributed in humans. Three polymorphic enzymes, CYP1A1, CYP2D6 and CYP2E1, have all been suggested as having roles in human lung carcinogenesis (Caporaso et al., 1991; Ingelman et al., 1992). The CYP1A1 gene is of critical importance for metabolism of polycyclic aromatic hydrocarbons. The gene product, aromatic hydrocarbon hydroxylase $(\mathrm{AHH})$, catalyses the first step in the conversion of many environmental car-cinogens such as benzo[a]pyrene to their ultimate DNA-binding carcinogenic form. The human gene is polymorphic, and two linked mutation sites, one of which is exon 7 (codon 462) and the other producing an Mspl restriction fragment length polymorphism (RFLP) in the 3 ' noncoding region, have been associated with increased risk for lung cancer in Asian but not in European populations (Kawajiri et al., 1990; Hayashi et al., 1991a; Tefre et al., 1991; Hirvonen et al., 1992). The homozygous variant of this genotype is found in $13 \%$ of Asians but in only $2 \%$ of Caucasians (Cosma et al., 1993), which might explain the discrepancies between case control studies using relatively small population number of predominantly one racial group.

Glutathione S-transferases are a large family of detoxi-fication enzymes that appear to form a part of protection mechanisms against chemical carcinogenesis (Mannervik et al., 1988; Board et al., 1990). There are four subclasses in mammalian cells, Alpha, Mu, Pi and Theta (Mannervik et al., 1992). The M1 member of the mu subclass is poly-morphic, being expressed in only 50$60 \%$ of Caucasians because of a gene deletion on the 'null' allele (Board et al., 1981a; 1981b; Seidegard et al., 1988). Previous studies have shown that the homozygous null genotype is more common among patients with colorectal cancer (Strange et al., 1991; Zhong et al., 1993), squamous cell carcinoma of the lung (Hirvonen et al., 1993), and other lung cancers (Seidegard et al., 1990; Kihara et al., 1993). This suggests that GSTM1 null individuals are more susceptible to certain types of cancer. Recent evidence suggests this to be true even for cutaneous cancers in which chemical carcinogenesis may not play such a big role (Heagerty et al., 1994). However, there have also been some conflicting reports, particularly in regard to 
lung cancer susceptibility (Brockmüler et al., 1993).

The present study was undertaken to establish the frequencies of the polymorphic genotypes of CYP1A1 and GSTM1 in Korean, and to evaluate linkage disequilibrium of the genotypes associated with high lung cancer risks among Korean lung cancer patients.

\section{Materials and Methods}

\section{Sample collection}

Blood samples from 85 lung cancer patients and 63 controls were obtained from the Mok Dong Hospital of Ewha Womans University, and Sam Sung Medical Center. The patients were diagnosed histologially as squamous cell carcinoma $(n=27)$, small cell carcinoma $(n=15)$, adenocarcinoma $(n=28)$ and others $(n=15)$.

\section{Genotyping for P4501A1 and GSTM1 genes}

Blood genomic DNA were isolated using the QIAamp blood kit (Qiagen Inc, Chatsworth, U.S.A.). The PCR analyses of Mspl and Ile-Val polymorphism in CYP1A1 were performed essentially as described (Hayashi et al., 1991b; Nakachi et al., 1991). The polymorphic site on the $3^{\prime}$ end of CYP1A1 was introduced due to a base substitution of $C$ to $T$ at $264 \mathrm{bp}$ downstream from the poly $(A)$ signal. DNA was amplified using primers with sequences of 5'-CAGTGAAGAGGTGTAGCC GC-3' and 5'-TAGGAGTCTTGTCTCATGCC-3'. PCR reactions were performed for 30 cycles of $95^{\circ} \mathrm{C}$ for $1 \mathrm{~min}, 68^{\circ} \mathrm{C}$ for $1 \mathrm{~min}$, and $72^{\circ} \mathrm{C}$ for $1 \mathrm{~min}$. The amplified fragments containing Mspl site were digested with Msp1 for $2 \mathrm{~h}$ at $37^{\circ} \mathrm{C}$, and the products were subjected to electrophoresis on $1.8 \%$ agarose gel and visualized by ethidium bromide staining. The Ile-Val polymorphism on the 7th exon arises from a $A \rightarrow G$ base change, which results in the replacement of isoleucine by valine at residue 462 in the heme binding region of the enzyme. For exon 7 polymorphism analysis, DNA was amplified in a separate reaction using one of two sense primers, either 5'GAAGTGTATCGGTGAGACCA-3' (1A1A) or 5'GAAGTGTATCGGTGAGACCG-3' (1A1G). Both reactions included the antisense primer, 5'-GTAGA CAGAGTCTAGGCCTCA-3'. PCR reactions were performed for 30 cycles at the same conditions as above. The two resulting PCR products were subjected to agarose gel electrophoresis in parallel lanes.

GSTM1 genotyping was performed as described (Cantlay et al., 1994). The sequences of oligonucleotides used to amplify the target DNA were : GSTM1 sense primer, 5'-CTGCCCTACTTGATTGATTGGG-3', and antisense primer, 5'-TTCTGGATTGTAGCAGATCA-3'. PCR reactions were performed for 30 cycles of $94^{\circ} \mathrm{C}$ for $1 \mathrm{~min}, 55^{\circ} \mathrm{C}$ for $1 \mathrm{~min}$ and $72^{\circ} \mathrm{C}$ for $1 \mathrm{~min}$. The PCR products were electrophoresed on $2 \%$ agarose gels and stained with ethidium bromide.

\section{Statistical analysis}

The $\chi^{2}$-test was used to test differences in the distribution of allele in CYP1A1 and GSTM1 between controls and lung cancer patients.

\section{Results}

\section{Distribution of CYP1A1 genotypes among controls and lung cancer patients}

CYP1A1 Ile/Val polymorphism was resulted from the replacement of lle by $\mathrm{Val}$ at residue 462 in the hemebinding region. We compared frequencies of three genotypes of CYP1A1 gene, a predominant homozygote (Ile/lle), a heterozygote (Ile/Val), and a rare homozygote (Val/Val), in lung cancer patients and controls (Table 1, Figure 1). Allele frequencies of the predominant homozygote (lle/lle), a heterozygote (lle/Val), and a rare homozygote ( $\mathrm{Val} / \mathrm{Val})$ were $3 \%, 95 \%$ and $2 \%$ in the control groups, and $19 \%, 80 \%$ and $1 \%$ in the lung cancer patients, respectively. The distribution of the three genotypes of

Table 1. Distribution of CYP1A1(lle/Val) genotypes among controls andlung cancer patients.

\begin{tabular}{|c|c|c|c|c|c|c|c|}
\hline \multirow{2}{*}{ Populations } & \multirow{2}{*}{$\mathrm{n}$} & \multicolumn{3}{|c|}{ CYP1A1(Ile/Val)genotypes } & \multirow{2}{*}{ OR } & \multirow{2}{*}{$95 \% \mathrm{Cl}$} & \multirow{2}{*}{$\mathrm{P}$} \\
\hline & & Ile/lle & Ile/Val & $\mathrm{Val} / \mathrm{Val}$ & & & \\
\hline Control & 63 & $2(3)^{a}$ & $60(95)$ & $1(2)$ & & & \\
\hline $\begin{array}{l}\text { Lung } \\
\text { Cancer }\end{array}$ & 85 & $16(19)$ & $68(80)$ & $1(1)$ & 0.14 & $0.03-0.64$ & 0.004 \\
\hline$S Q^{b}$ & & $7(26)$ & $19(70)$ & $1(4)$ & 0.09 & $0.02-0.49$ & 0.001 \\
\hline $\mathrm{SC}^{\mathrm{C}}$ & & $3(20)$ & $12(80)$ & $0(0)$ & 0.13 & $0.02-0.87$ & 0.017 \\
\hline$A D^{d}$ & & $4(14)$ & $24(83)$ & $0(0)$ & 0.01 & $0.01-0.06$ & 0.000 \\
\hline Others & & $2(13)$ & $13(87)$ & $0(0)$ & 0.21 & $0.03-1.65$ & 0.109 \\
\hline
\end{tabular}

a Numbers in parentheses are percentage ${ }^{b}$ Squamous cell carcinoma

${ }^{\mathrm{c}}$ Small cell carcinoma

${ }^{\mathrm{d}}$ Adenocarcinoma 

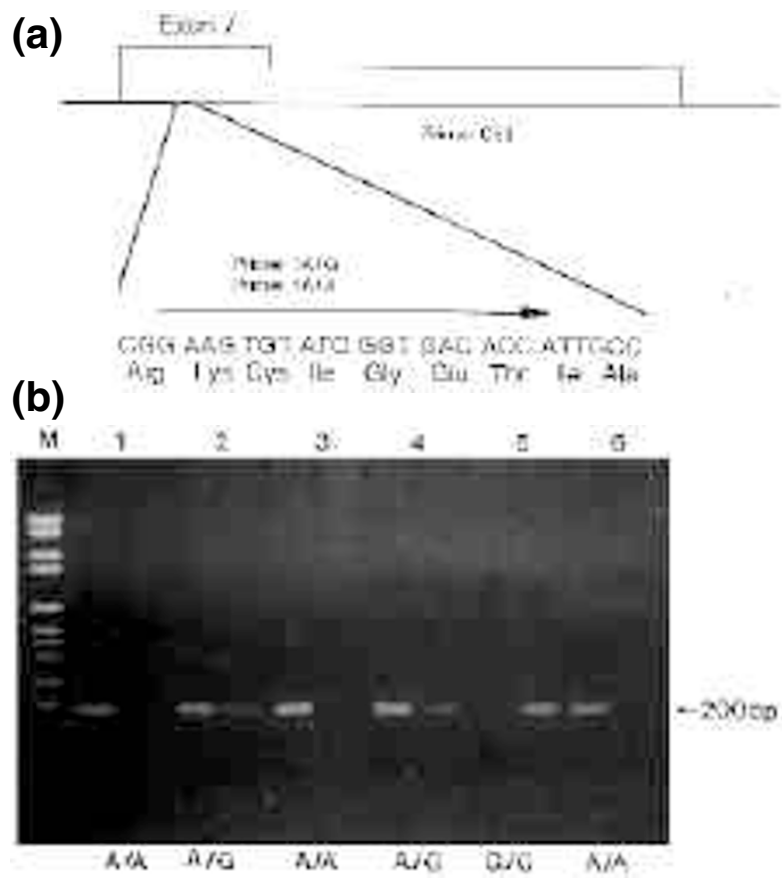

Figure 1. Detection of genotypes of the CYP1A1 gene by PCR. (a) Structure of the polymorphic site in exon 7 of the CYP1A1 gene. The primers used in the PCR are shown by arrows. (b) Results of PCR detection in cancer patients. Patients 1, 3 and 6 were identified as a homozygote of lle (A/A) since they generated 200bp product only when the primer $1 \mathrm{~A} 1 \mathrm{~A}$ was used (left lane), no product when the primer $1 \mathrm{~A} 1 \mathrm{G}$ was used (right lane). Patient 5 wasidentified as a homozygote of Val (G/G) because a PCR product wasobtained using $1 \mathrm{~A} 1 \mathrm{G}$ (right lane) but not $1 \mathrm{~A} 1 \mathrm{~A}$ (left lane). Patient 2 and 4 were heterozygous $(A / G)$ since $P C R$ products were observed in both primer reactions.

CYP1A1 (lle/Val) was different between the lung cancer patient and the control groups $\left(\chi^{2}\right.$-test; $\left.p=0.004\right)$. Valcontaining genotypes (lle/Val, $\mathrm{Val} / \mathrm{Val}$ ) were significantly more prevalent among the controls than the lung cancer patients (OR, $0.14 ; 95 \% \mathrm{Cl}, 0.03-0.61$ ). When the lung cancer patients were divided into subgroups based on

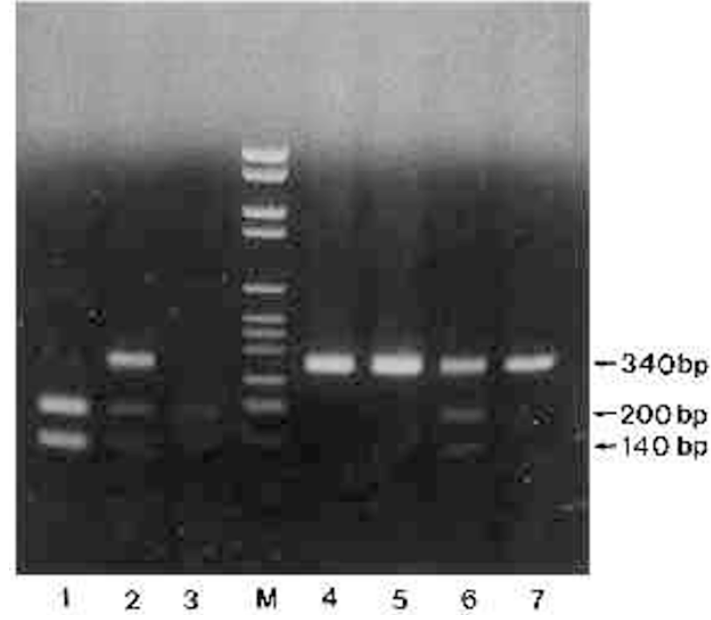

Figure 2. DNA polymorphism of the CYP1A1 gene by Msp1. The 3'-end of CYP1A1 in blood genomic DNA was amplified by PCR. The resulting PCR fragments were digested with Mspl and analysed on $1.8 \%$ agarose gel electrophoresis as described in Materials and Methods. Lane 1 and 3: homozygous variant $(\mathrm{m} 2)$, Lane 2 and 6: heterozygous (m1/m2), Lane 4, 5 and 7: homozygous normal (m1), Lane M, marker.

histological diagnoses, frequencies of Val-containing genotypes were significantly less in squamous cell carcinoma patients than in control groups $(p=0.001$; OR, $0.09 ; 95 \% \mathrm{Cl}, 0.018-0.048)$. The proportions, however, in adenocarcinoma patient groups were not different significantly from the control groups.

We also compared the genotypes of CYP1A1(Mspl) polymorphism (Table 2, Figure 2). The Mspl restriction site polymorphism resulted in three genotypes; a predominant homozygous $\mathrm{m} 1$ allele without Mspl site (generates $340 \mathrm{bp}$ fragment, genotype A), the heterozygote (generates 340, 200 and 140 bp fragments, genotype $\mathrm{B})$ and a rare homozygous $\mathrm{m} 2$ allele with the Mspl site (generates 200 and $140 \mathrm{bp}$ fragments, genotype C). The proportions of $\mathrm{m} 1 / \mathrm{m} 1, \mathrm{~m} 1 / \mathrm{m} 2$ and $\mathrm{m} 2 / \mathrm{m} 2$ genotypes in

Table 2. Distribution of CYPIA1(Mspl) genotypes among controls andlung cancer patients.

\begin{tabular}{|c|c|c|c|c|c|c|c|}
\hline \multirow[b]{2}{*}{ Populations } & \multirow[b]{2}{*}{$\mathrm{n}$} & \multicolumn{3}{|c|}{ CYPIA1(Msp1)genotypes } & \multirow[b]{2}{*}{ OR } & \multirow[b]{2}{*}{$95 \% \mathrm{Cl}$} & \multirow[b]{2}{*}{$\mathrm{P}$} \\
\hline & & $\begin{array}{l}\text { homozygous } \\
\text { normal(m1/m1) }\end{array}$ & $\begin{array}{l}\text { heterozygous } \\
(\mathrm{m} 1 / \mathrm{m} 2)\end{array}$ & $\begin{array}{l}\text { homozygous } \\
\text { variant(m2/m2) }\end{array}$ & & & \\
\hline Control & 63 & $29(46)^{a}$ & $31(49)$ & $3(5)$ & & & \\
\hline $\begin{array}{l}\text { Lung } \\
\text { Cancer }\end{array}$ & 85 & $34(40)$ & $45(53)$ & $6(7)$ & 1.28 & $0.66-2.47$ & 0.463 \\
\hline$S Q^{b}$ & & $12(44)$ & $14(52)$ & $1(4)$ & 1.63 & $0.69-3.88$ & 0.267 \\
\hline $\mathrm{SC}^{\mathrm{c}}$ & & $5(36)$ & $8(57)$ & $1(7)$ & 1.55 & $0.50-4.83$ & 0.452 \\
\hline$A D^{d}$ & & $13(46)$ & $13(46)$ & $2(8)$ & 1.10 & $0.46-2.64$ & 0.842 \\
\hline Others & & $4(25)$ & $10(63)$ & $2(13)$ & 2.83 & $0.82-9.80$ & 0.091 \\
\hline
\end{tabular}

a Numbers in parentheses are percentage

${ }^{\mathrm{C}}$ Small cell carcinoma

b Squamous cell carcinoma

${ }^{\mathrm{d}}$ Adenocarcinoma 


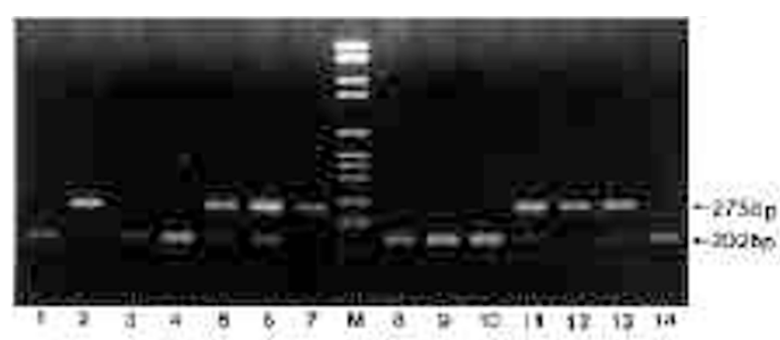

Figure 3. Detection ofGSTM1 genotypes by PCR. GSTM1 genotyping was conducted as described (Cantlay et al. 1994). GSTM1 positive type produced 275bp fragment (lanes 2, 5, 6, 7. 11, 12, and 13) andGSTM1 null type did not (lanes 1, 3, 4, 8, 9, 10, and 14). $M$ denotes for marker. The constant $202 \mathrm{bp}$ fragment was amplified as an internal control.

CYP1A1 were $46 \%, 49 \%$ and $5 \%$ in the control group, respectively. On the other hand, the lung cancer patient group showed $40 \% \mathrm{~m} 1 / \mathrm{m} 1,53 \% \mathrm{~m} 1 / \mathrm{m} 2$ and $7 \% \mathrm{~m} 2 / \mathrm{m} 2$ genotypes in CYP1A1. A slight increase in the $\mathrm{m} 1 / \mathrm{m} 2$ and $\mathrm{m} 2 / \mathrm{m} 2$ genotypes (56\%) was observed in the patient group with squamous cell carcinoma compared with the control group.

Table 3 showed the linkage distribution of CYP1A1 genotypes. In the control group, $90 \%$ (26/29) of the $\mathrm{m} 1 /$ $\mathrm{m} 1$ genotypes were associated with the lle/Val genotype and the remainder with the $\mathrm{m} 1 / \mathrm{m} 1$ genotype and $\mathrm{m} 2 / \mathrm{m} 2$ genotype. No subject was identified with Val/Val genotype. All of the $\mathrm{m} 1 / \mathrm{m} 2$ and $\mathrm{m} 2 / \mathrm{m} 2$ genotypes were associated with Ile/Val genotype. In lung cancer patients, 26\% (9/ 35 ) of the $\mathrm{m} 1 / \mathrm{m} 1$ genotypes were associated with Ile/lle genotype and $74 \%(26 / 38)$ of $\mathrm{m} 1 / \mathrm{m} 1$ genotype with llel/ Val genotype. But, $14 \%(6 / 44)$ of the $\mathrm{m} 1 / \mathrm{m} 2$ genotype were associated with Ile/lle genotype and $86 \%$ (38/44) of the $\mathrm{m} 1 / \mathrm{m} 2$ with Ile/Val genotype. One subject was identified with $\mathrm{m} 2 / \mathrm{m} 2$ genotype and $\mathrm{Val} / \mathrm{Val}$ genotype.

\section{Distribution of GSTM1 genotypes among controls and patients with lung cancer}

Table 4 shows the frequencies of the GSTM1 deletion genotype in controls and lung cancer patients (Figure 3). The frequency of GSTM1(-) genotype was $52 \%$ among the control group. Among 85 lung cancer patients of all the histological types, the frequency of GSTM1(-) genotype was increased to $55 \%$, however, it is not statistically significant $(p=0.46$; OR, $1.21 ; 95 \% \mathrm{Cl}, 0.59-2.16)$. When the lung cancer patients were grouped according to

Table 3. Distribution of combined CYPIA1 genotypes among controls and lung cancer patients.

\begin{tabular}{|c|c|c|c|c|c|c|c|}
\hline Populations & Genotypes & $\begin{array}{l}\text { homozygous } \\
\text { normal } \\
(\mathrm{m} 1 / \mathrm{m} 1)\end{array}$ & $\begin{array}{l}\text { heterozygous } \\
\text { (m1/m2) }\end{array}$ & $\begin{array}{l}\text { homozygous } \\
\text { variant } \\
\text { (m2/m2) }\end{array}$ & OR & $95 \% \mathrm{Cl}$ & $P$ \\
\hline \multirow[t]{4}{*}{ Controls } & Ile/lle & $2(100)^{a}$ & $0(0)$ & $0(0)$ & & & \\
\hline & Ile/Val & $26(43)$ & $31(52)$ & $3(5)$ & & & \\
\hline & $\mathrm{Val} / \mathrm{Val}$ & $1(100)$ & $0(0)$ & $0(0)$ & & & \\
\hline & Total & 29 & 31 & 3 & & & \\
\hline Lung & Ile/Ile & $9(60)$ & $6(40)$ & $0(0)$ & $1.67^{b}$ & $1.10-2.52$ & 0.26 \\
\hline Cancer & Ile/Val & $26(38)$ & $38(55)$ & $5(7)$ & $1.27^{c}$ & $0.63-2.56$ & 0.51 \\
\hline \multirow[t]{2}{*}{ Patients } & Val/Val & $0(0)$ & $0(0)$ & $1(100)$ & & & \\
\hline & Total & 35 & 44 & 6 & & & \\
\hline
\end{tabular}

${ }^{a}$ Numbers in parentheses are percentage.

${ }^{\mathrm{b}}$ OR calculated with Ile/lle(control) as a reference

${ }^{\mathrm{c}} \mathrm{OR}$ calculated with $\mathrm{lle} / \mathrm{Val}+\mathrm{Val} / \mathrm{Val}($ control) as a reference

Table 4. Distribution of GSTM1 genotypes among controls andlung cancerpatients.

\begin{tabular}{lcccccc}
\hline Populations & $\mathrm{n}$ & $\begin{array}{c}\text { GSTM1 } \\
(+)\end{array}$ & $\begin{array}{c}\text { genotypes } \\
(-)\end{array}$ & OR & $95 \% \mathrm{Cl}$ & $\mathrm{P}$ \\
\hline $\begin{array}{l}\text { Controls } \\
\text { LungCancer }\end{array}$ & 63 & $30(48)^{\mathrm{a}}$ & $33(52)$ & & & \\
patients & 85 & $38(45)$ & $47(55)$ & 1.12 & $0.59-2.16$ & 0.460 \\
SQb & & $12(44)$ & $15(56)$ & 1.13 & $0.46-2.81$ & 0.782 \\
SMc & & $8(57)$ & $6(43)$ & 0.68 & $0.21-2.19$ & 0.519 \\
ADd & & $12(43)$ & $16(57)$ & 1.21 & $0.49-2.97$ & 0.674 \\
Others & & $6(38)$ & $10(62)$ & 1.52 & $0.49-4.67$ & 0.468 \\
\hline
\end{tabular}

a Numbers in parentheses are percentage

c Small cell carcinoma

b Squamous cell carcinoma

${ }^{d}$ Adenocarcinoma 
Table 5. Distribution of combined CYP1A1(Msp1) and GSTM1 genotypesamong controls and lung cancer patients.

\begin{tabular}{llccccc}
\hline Populations & \multicolumn{1}{c}{$\mathrm{n}$} & $\begin{array}{c}\text { GSTM1 } \\
(+)\end{array}$ & $\begin{array}{c}\text { genotypes } \\
(-)\end{array}$ & OR & $95 \% \mathrm{Cl}$ & $\mathrm{P}$ \\
\hline Controls & $\mathrm{m} 1 / \mathrm{m} 1$ & $11(42)^{\mathrm{a}}$ & $15(58)$ & & & \\
& $\mathrm{m} 1 / \mathrm{m} 2$ & $18(53)$ & $16(47)$ & & & \\
& $\mathrm{m} 2 / \mathrm{m} 2$ & $1(33)$ & $2(67)$ & & & \\
& total & 30 & 33 & & & \\
Lung & $\mathrm{m} 1 / \mathrm{m} 1$ & $14(40)$ & $21(60)$ & $1.10^{\mathrm{b}}$ & $0.39-3.08$ & 0.856 \\
Cancer & $\mathrm{m} 1 / \mathrm{m} 2$ & $21(49)$ & $22(51)$ & $1.18^{\mathrm{c}}$ & $0.48-2.90$ & 0.721 \\
Patients & $\mathrm{m} 2 / \mathrm{m} 2$ & $3(43)$ & $4(57)$ & $1.50^{\mathrm{d}}$ & $0.09-25.39$ & 0.778 \\
& total & 38 & 47 & & & \\
\hline
\end{tabular}

${ }^{a}$ Numbers in parentheses are percentage ${ }^{b}$ OR calculated with $\mathrm{m} 1 / \mathrm{m} 1$ (control) as a reference

${ }^{c}$ OR calculated with $\mathrm{m} 1 / \mathrm{m} 2$ (control) as a reference

${ }^{\mathrm{d}} \mathrm{OR}$ calculated with $\mathrm{m} 2 / \mathrm{m} 2$ (cOntrol) as a reference

histological types, no significant increase in the GSTM1(-) genotype was observed in the squamous cell carcinoma and adenocarcinoma groups, and frequency of GSTM1(-) genotype was decreased slightly in small cell carcinoma $(p=0.519$; OR, 1.13; 95\% Cl 0.46-2.81). Table 5 shows combined genotypes of CYP1A1(Mspl) and GSTM1 polymorphisms. In the lung cancer patients, there was a slight elevation of frequency of the m2 allele among GSTM1(-) individuals compared to GSTM1(+) individuals.

\section{Discussion}

Genetic polymorphism in drug metabolizing enzymes has been found to be a factor in an individual's suscepti-bility to cancer. Among several candidates for a high risk allele for lung cancer, cytochrome 450 has been investi-gated most extensively because of its potential involvement in chemical carcinogenesis. Thus, CYP1A1 Mspl poly-morphism and polymorphism of its exon 7 catalytic site have been reported to be related to lung cancer risk in at least one study, although studies carried out in different populations have not always yielded consistent results. Our results in this study indicate no difference in the genotypic frequencies of CYP1A1 Mspl polymorphism and a significant different CYP1A1 lle/Val polymorphism between control and lung cancer patient groups. Our results on the CYP1A1 genotypes are not in agreement with the following two previous reports. It was reported that there was a statistically significant association between the rare $\mathrm{m} 2$ allele and certain types of lung cancer, and that frequencies of genotypes among lung cancer patients were significantly different from those among healthy controls (Kawajiri et al., 1990). The genotype frequencies in squamous cell carcinoma as diagnosed histologically were remarkably deviated from those in the healthy controls; approximately 5 -fold risk of $\mathrm{m} 2 / \mathrm{m} 2$ type was calculated for this smoking-related type of lung cancer. It was also reported that smokers with the susceptible genotype were at a remarkably high risk at a low dose level of cigarette smoking while the difference between the genotypes was reduced at high dose levels (Nakachi et al., 1991). In contrast to these findings, a similar study on Norwegian lung cancer patients showed no statistically significant differences in allelic frequencies or distribution of the CYP1A1 genotypes (Tefre et al., 1991). It is evident that more studies using larger study populations from various ethnic subgroups are necessary to draw any definitive conclusions concerning a possible association between polymorphism in the cytochrome P450 gene superfamily and lung cancer risk.

GSTM1 deletion polymorphism has attracted much attention owing to its possible association with increased susceptibility to certain malignancies such as lung cancer (Zhong et al., 1991), astrocytoma (Strange et al., 1992), stomach cancer (Harada et al., 1992), and pituitary adenoma (Fryer et al., 1993). An association between deficient GSTM1 activity and an increased risk of adenocarcinoma of the lung among smokers would be a cofounding factor (Seidegard et al., 1990). And some studies suggested that the GSTM1 null genotype is associated with increased risk of squamous cell carcinoma of lungs which is the lung cancer most clearly related to smoking (Hirvonen et al., 1993; Kihara et al, 1994). On the other hand, other authors found a significant negative correlation between adenocarcinoma of lung and the GSTM1 null genotype and a significant positive correlation to adenocarcinoma of colon (Zhong et al., 1991; 1993). Our data, however, failed to demonstrate any statistically significant difference in the GSTM1 genotype distribution among the GSTM1 null lung cancer patients, although a higher proportion of the subjects exhibited the GSTM1 null genotype compared 
to the controls ( $p=0.46$; OR, 1.12; $95 \% \mathrm{Cl}, 0.59-2.16$ ). The reason for this is not clear. The consequence of the GSTM1 polymorphism still remains unclear. The central role of GST in detoxification implies that sensitivity to chemical toxins and carcinogen may be affected by this polymorphism. We conclude that, polymorphic expression of the GSTM1 isozyme appears to be linked to individual's sensitivity to chemical carcinogens, however, this cannot explain all of the observed individual variations.

\section{Acknowledgement}

This work was supported by Ewha Womans University Research Fund.

\section{References}

Board, P. G. (1981a) Biochemical genetics of glutathione S-transferase in man. Am. J. Hum. Genet. 33: 36-43

Board, P. G.(1981b) Gene deletion and partial deficiency of the glutathione Stransferase (ligand in) system in man. FEBS Lett. 135: 12-14

Board, P. G., Coggan, M., Johnson, P., Ross, V., Suzuaki, T. and Wegg, G. (1990) Genetic heterogeneity of the human glutathione transferase: a complex of gene families. Pharmac. Ther. 48: 357-369

Brockmüler. J., Kerb, R., Drakoulis, N., Nitz, M. and Roots, I. (1993) Genotype and phenotype of glutathione S-transferase class $\mu$ and $\Psi$ in lung cancer patients and controls. Cancer Res. 53: 11004-11011.

Cantlay, A. M., Smith, C. A. D., Wallace, W. A., Yap, P.-L., Lamo, D., Harrison, D. J. (1994) Heterozygous expression and polymorphic genotypes of glutathione-Stransferase in human lung. Thorax. 49: 1010-1014

Caporaso, N., Landi, M. and Vineis, P. (1991) Relevance of metabolic polymorphisms to human carcinogenesis: evaluation of epidemiologic evidence. Pharmacogenetics 1: 4-19

Cosma, G. N., Crofts, F., Currie, D., Wirgin, I., Toniolo, P. and Garte, S. J. (1993) Racial differences in restriction fragment length poly-morphism and mRNA inducibility of the human CYP1A1. Cancer Epidemiol. Biomark. Prevent. 2: 53-57

Freyer, A. A., Zhao, L., Alldersea, J., Boggild, M. D., Perrett, C. W., Clayton, R. N., Jones, P. W. and Strange, R. C. (1993) The glutathione S-transferase: polymerase chain reaction studies on the frequency of the GSTM1 genotype in patients with pituitary adenomas. Carcino-genesis 14: 563-566

Harada, S., Misawa, S., Nakamura, T., Tanaka, N., Ueno, E. and Nozoe, M. (1992) Detection of GSTM1 gene deletion by the polymerase chain reaction and its possible correlation with stomach cancer in Japanese. Hum. Genet. 90: 62-64

Hayashi, S.-I., Watanabe, J., Nakachi, K. and Kawajiri, K. (1991a) Genetic linkage of lung cancer-associated Mspl polymorphism with amino acid replacement in the heme binding region of the human cytochrome P4501A1 gene. J. Biochem. 110: 407-411

Hayashi, S.-I., Watanabe, J., Nakachi, K. and Kawajiri, K (1991b) PCR detection of an A/G polymorphism within exon 7 of the CYP1A1 gene. Nucleic Acids Res. 19: 4797

Heagerty. A. H. M., Fitzgerald, D., Smith. A., Bower, B., Jones. P., Fryer, A. A., Zhao, L., Alldersea. J. and Strange. R. C. (1994) Glutathione S-transferase (GSTM1) phenotypes protection against cutaneous tumours. Lancet 343: 266-268

Hirvonen, A., Husgafvel-Pursiainen, K., Karjalainen, A., Anttila, S. and Vainio, H. (1992) Point-mutational Mspl and lle-Val polymorphism closely linked in the CYP1A1 gene: lack of association with suscepti-bility to lung cancer in Finnish study population. Cancer Epidemiol. Biomark. Prevent. 1: 485-489
Hirvonen, A., Husgafvel-Pursiamen, K., Anttila, S. and Vainio, H. (1993) The GSTM1 null genotype as a potential risk modifier for squamous cell carcinoma of the lung. Carcinogenesis 14: 1479-1481

Idle, J. R. (1991) Is environmental carcinogenesis modulated by host polymorphism? Mutat. Res. 247: 259-266

Ingelman Sundberg, M., Johansson, I., Persson, I., Yue, Q.-Y., Dahl, M., Bertilsson, L. and SjÖqvist, F. (1992) Genetic polymorphism of cytochromes P450: interethnic differences and relationship to incidence of lung cancer. Pharmacogenetics 2: 264-271

Kawajiri, K., Nakachi, K., Imai, K., Yoshii, A., Shinoda, N. and Watanabe, J. (1990) Identification of genetically high risk individuals to lung cancer by DNA polymorphisms of the cytochrome P4501A1 gene. FEBS Lett. 263: 131-133

Kihara, M., Noda, K. and Okamoto, N. (1993) Increased risk of lung cancer in Japanese smokers with class mu glutathione S-transferase gene deficiency. Cancer Lett. 71: 151155

Kihara, M., Kihara, M. and Noda, K. (1994) Lung cancer risk of GSTM1 null genotype is dependent on the extent of tobacco smoke exposure. Carcingenesis 15: 415-418

Mannervik, B. and Danielson, U. H. (1988) Glutathione transferase-structure and catalytic activity. CRC Critical Review in Biochemistry 23: 283-337

Mannervik, B., Awasthi, Y. C., Board, P. G., Yayes, J. D., Di llio C., Ketterer, B., Listowsky, I., Morgenstern, R., Muramatsu, M., Pearson, W. R. Pickett, C. B., Sato, K., Widersten, M. and Wolf, C. R. (1992) Nomenclature for human glutathione transferase. Biochem. J. 282: 305-308

Nakachi, K., Imai, K., Hayashi, S.-I, Watanabe, J. and Kawajiri, K. (1991) Genetic susceptibility to squamous cell carcinoma of the lung in relation to cigarette smoking dose. Cancer Res. 51: 5177-5180

Nebert, D. W. (1991)Role of genetics and drug metabolism in human cancer risk. Mutat. Res. 247: 267-281

Seidegard, J., Vorachek, W. R., Pero, R. W. and Pearson, W. R. (1988) Hereditary differences in the expression of the human glutathione transferase activity on transstilbene oxide are to a gene deletion. Proc. Natl. Acad., Sci. USA 85: 7293-7297

Seidegard, J., Pero, R. W., Markowitz, M. M., Roush, G., Miller, D. G. and Beattie, E. J. (1990) Isoenzyme(s) of glutathione transferase (class $\mu$ ) as a marker for susceptibility to lung cancer: a follow up study. Carcinogenesis 11: 33-36

Strange, R. C., Matharoo, B., Faulder, G. C., Cotton, W., Elder, J .B. and Deakin M. (1991) The human glutathione-S-transferase: a case-control study of the incidence of the GSTM1 0 phenotype inpatients with adenocarcinoma. Carcinogenesis 12: 25-28

Strange, R. C., Fryer, A. A., Matharoo, B., Zhao, L., Broome, J., Campbell, D. A., Jones, P., Pastor, I. J. and Singh, R. V. P. (1992) The human glutathione-S-transferase: comparison of isozyme expression in normal and astrocytoma brain. Biochem. Biophys. Acta. 1139: 222-228

Tefre, T., Ryber, D., Haugen, A., Nebert, D. W., Skaug, V., Broggeer, A. and Borresen, A.-L. (1991) Human CYP1A1 (cytochrome P1-450) gene: lack of association between the Mspl restriction fragment length polymorphism and incidence of lung cancer in a Norweigian population. Pharmacogenetics 1: 20-25

Zhong, S., Howie, A. F., Ketterer, B., Taylor, J., Hayes. J. D., Beckette, G., Wathen, C. G. Wolf,C. R. and Spurr, N. K. (1991) Glutathione S-transferase mu locus : use of genotyping and phenotyping assays to assess association with lung cancer susceptibility. Carcinogenesis 12: 1533-1537

Zhong, S., Wyllie, H., Barnes, D., Wolf, C.R. and Spurr, N. K. (1993) Relationship between the GSTM1 genetic polymorphism susceptibility to bladder, breast and colon cancer. Carcinogenesis 14: 1821-1824 
Exp. Mol. Med. 